\title{
Why Family Firms Are Like Jenga
}

\section{Kimberly Eddleston (Northeastern University)}

KEYWORDS: Entrepreneurship, Management, Family

Business.

With ties that bind emotionally and legally, family businesses are different from non-family firms: sensitive, easily disrupted and conflict-prone. But in this interview with EIX Editor Kim Eddleston, Doug Baumoel of Continuity Family Business Consulting argues that family businesses must find a way to innovate nonetheless, even if it brings conflict and discomfort. 